\title{
Level of PD-1 expression on CD8+ T cells influence prognosis and respond to PD-1 therapy in a murine model
}

\author{
Benjamin A Kansy ${ }^{1 *}$, Raghvendra M Srivastava², Hyun-Bae Jie², Gulidanna Shayan², Yu Lei ${ }^{2}$, Jing Li ${ }^{2}$, \\ William Gooding ${ }^{3}$, Sven Brandau ${ }^{4}$, Stephan Lang ${ }^{4}$, Nicole Schmitt ${ }^{5}$, Gordon J Freeman ${ }^{6}$, David A Clump ${ }^{7}$, \\ Robert L Ferris ${ }^{2}$ \\ From 30th Annual Meeting and Associated Programs of the Society for Immunotherapy of Cancer \\ (SITC 2015) \\ National Harbor, MD, USA. 4-8 November 2015
}

\section{Introduction}

Prognosis varies dramatically in head and neck squamous cell carcinoma (HNSCC) based on HPV status. In $\mathrm{HPV}^{+}$ patients, programmed death (PD)-1 expression has been linked to a better clinical outcome. We hypothesized that extent of PD-1 expression may differentially impact $\mathrm{T}$ cell phenotype, patient prognosis and response to anti-PD-1 immunotherapy in a murine $\mathrm{HPV}^{+}$cancer model.

\section{Material and methods}

Freshly isolated tumor infiltrating lymphocytes (TIL) from HNSCC patients were stained by flow cytometry for expression level of PD-1 expression (PD- $1^{\text {high }}$ vs. PD- ${ }^{\text {low }}$ ), granzyme $\mathrm{B}$, or IFN-y secretion by ELISPOT. The prognostic impact of PD- $1^{\text {high }}$ vs. PD- ${ }^{\text {low }}$ T cells was determined in a cohort of HNSCC patients $(n=56$, median follow up $=19 \mathrm{mo}$ ). In a murine HNSCC model, PD- $1^{\text {high }}$ and $\mathrm{PD}-1^{\text {low }}$ fractions were compared from $\mathrm{CD} 3^{+} \mathrm{CD} 8^{+}$ PD $-1^{+}$cells and analyzed according to different treatment groups (untreated, anti-PD-1 mAb, radiotherapy and 3 different anti-PD-1/radiotherapy combinations).

\section{Results}

CTLA-4 and PD-1 were significantly upregulated on both $\mathrm{HPV}^{+}$and $\mathrm{HPV}^{-} \mathrm{HNSCC}$ patients' TIL, whereas PD- $1^{+}$ $\mathrm{CD}^{+}$cells were significantly enriched in TIL from $\mathrm{HPV}^{+}$ patients $(\mathrm{p}=0.006)$. Interestingly, $\mathrm{PD}-\mathrm{1}^{\text {high }}$ cells represented a more dysfunctional phenotype, with severely

${ }^{1}$ Department of Otorhinolaryngology, University Hospital Essen, Germany; University of Pittsburgh Cancer Institute, Pittsburgh, PA, USA Full list of author information is available at the end of the article compromised IFN- $\gamma$ secretion (phigh CD8 ${ }^{+}$TIL were more likely to be $\mathrm{HPV}^{-}$and had a worse disease free survival $(\mathrm{HR}=2.25 ; 95 \% \mathrm{CI}=1.46-3.15 ; \mathrm{p}<.0001)$, while high fractions of $\mathrm{PD}-1^{\text {low }} \mathrm{T}$ cells were associated with better clinical outcome $(\mathrm{HR}=0.19,95 \% \mathrm{CI}=.07-.49$, $\mathrm{p}=.0006$ ), and were seen preferentially in $\mathrm{HPV}^{+} \mathrm{HNSCC}$ patients. In the murine HNSCC model, anti-PD-1 mAb plus radiotherapy resulted in optimal tumor elimination, which was associated with an elimination of PD-1 ${ }^{\text {high }}$ $\mathrm{CD}^{+} \mathrm{T}$ cells and - most importantly - increase in PD-1 ${ }^{\text {low/intermed }} \mathrm{T}$ cell frequencies $(\mathrm{p}<0.5)$.

\section{Discussion}

Consideration of different PD-1 expression levels on TIL segregates PD-1 expression as a marker of activated, competent tumor reactive $\mathrm{T}$ cells on the one hand (low/ intermed expression), and as a marker of exhausted, dysfunctional cells in the tumor microenvironment on the other hand (high expression). These results emphasize the crucial role of differential PD-1 expression levels on HNSCC patients' effector T cells for prognosis and as a potential novel biomarker for anti-PD-1/PD-L1 based immunotherapy.

\footnotetext{
Authors' details

'Department of Otorhinolaryngology, University Hospital Essen, Germany; University of Pittsburgh Cancer Institute, Pittsburgh, PA, USA. ${ }^{2}$ University of Pittsburgh Cancer Institute, Pittsburgh, PA, USA. ${ }^{3}$ Biostatistics Facility, University of Pittsburgh Cancer Institute, Pittsburgh, PA, Pittsburgh, PA, USA ${ }^{4}$ Department of Otorhinolaryngology, University Hospital Essen, Germany, Essen, Germany. ${ }^{5}$ Department of Otolaryngology, University of Pittsburgh, Pittsburgh, PA, Pittsburgh, PA, USA. 'Dana-Farber/Harvard Cancer Center,
} 
Cite this article as: Kansy et al: Level of PD-1 expression on CD8+

$\mathrm{T}$ cells influence prognosis and respond to PD-1 therapy in a murine model. Journal for ImmunoTherapy of Cancer 2015 3(Suppl 2):P228.

Submit your next manuscript to BioMed Central and take full advantage of:

- Convenient online submission

- Thorough peer review

- No space constraints or color figure charges

- Immediate publication on acceptance

- Inclusion in PubMed, CAS, Scopus and Google Scholar

- Research which is freely available for redistribution

Submit your manuscript at www.biomedcentral.com/submit 